\title{
TOTALITĀRISMS ZEM KOMUNISMA MASKAS
}

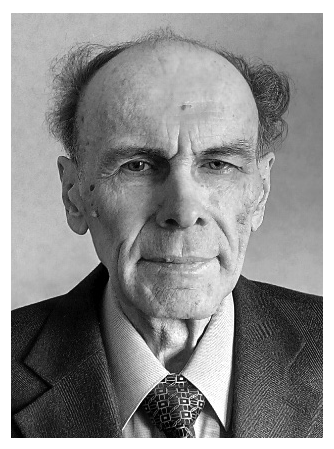

Andris Kleinhofs ir ekonomikas zinātṇu doktors, profesors (2001), Krievijas Dabaszinātṇu akadēmijas īstenais loceklis (1999). Aizstāvējis ekonomikas zinātṇu kandidāta disertāciju Meža nozares plānošanas sistēmas pilnveidošana (1971) un ekonomikas zinātnu doktora disertāciju Meža nozares pāreja uz tirgus ekonomikas principiem. Teorija un metodologija (1992). Dzimis 1937. gada 9. jūijā Latvijā, Dundagas pagastā, zemnieku Almas Valdreihas un Eduarda Kleinhofa gímenē. Bērnība pavadīta Dundagas Grabēs, skolas gadi Kazdangā un Sieksātē. Studējis Latvijas Lauksaimniecības akadēmijas Mežsaimniecības fakultātē (1956-1962), ko beidzis kā inženieris mežkopis. Iestājies aspirantūrā Vissavienības mežsaimniecības un meža mehanizācijas zinātnieciskās pētniecības institūtā (Vserossiyskiy nauchno-issledovatel'skiy institut lesovodstva i mehanizatsii lesnogo hozyaystva) - VNIILM (1966-1969). Strādājis Viḷakas mežrūpniecības saimniecībā par inženieri (1962-1963), Latvijas PSR ZA Mežsaimniecības problēmu un koksnes ķīmijas institūtā par jaunāko zinātnisko līdzstrādnieku (1963-1966), Maskavā, VNIILM, vecākais zinātniskais līdzstrādnieks (1969-1971), projektēšanas un zinātniskās pētniecības institūta Sojuzgiproleshoz Meža ekonomikas dą̧as vadītājs (1972-1974). VNIILM vadošais zinātniskais līdzstrādnieks, sektora vadītājs (1976-1991) un Mežsaimniecības stratēǵiskās attīstības dalıas vadītājs (1991-1998), Zinātniskās padomes loceklis. Profesors Maskavas Valsts meža universitātes Pasaules ekonomikas un ārējo ekonomisko sakaru katedrā (1998-2007), K. Razumovska Maskavas Valsts tehnoloǵiju un vadības universitātes Mārketinga katedrā (2007-2012), Maskavas Valsts ūdens transporta akadēmijas Mārketinga katedrā (2012-2014), Maskavas Finanšu humanitārās akadēmijas Valsts un pašvaldību vadības katedrā (2014-2015). Eksperts Krievijas Federācijas Padomes darba grupā Valsts dabas resursu vadības sistēmas izstrādei tirgus ekonomikas apstākḷos (1992-1994). Latvijas valdības izsludinātā konkursa Meža nozares vadība tirgus ekonomikas apstākḷos laureāts (1993). Doktora disertāciju padomes loceklis Maskavas Valsts meža universitātē (1993-2013) un Maskavas Vieglās rūpniecības institūtā (2007-2012). Ekonomikas zinātņu doktoru (2) un kandidātu (5) disertāciju zinātniskais vadītājs. Starptautisku zinātniskās pētniecības projektu vadītājs ekonomikas un ilgtspējīgās attīstības pārvaldībā (8). Ar ziņojumiem piedalījies starptautiskās konferencēs un kongresos (13). Publicējis vairāk nekā 140 zinātnisku darbu latviešu, krievu, angḷu un vācu valodā.

Raksturvārdi: viltus zinātne, totalitārais režīms, marksisms, proletariāta diktatūra, informācijas manipulācijas.

\section{Mihails Lermontovs:}

Kḷūs asinis un nāve daudzu prieks;

Kad bērnus, nevainīgas sievas vairs

Ne glābs, ne sargās likums satriektais. (Atdz. Rainis)

Par Padomju Savienībā pastāvējušā boḷševiku režīma darbības dažādiem aspektiem un tā noziegumiem ir sakrājies vesels publikāciju kalns. Ir uzrakstītas daudzas grāmatas, uzṇemtas dokumentālās un mākslas filmas. Krievu dzejnieks M. L,ermontovs boḷševiku asiņainā režīma noziegumus paredzēja dzejolī, ko viņš uzrakstīja jau 1830. gadā. Vladimira L,enina attīstītā marksisma-ḷeṇinisma teorija līdz šim nereti tiek identificēta ar Kārḷa Marksa un Frīdriha Engelsa komunistiskās sabiedrības attīstības teoriju, nepietiekamu vērību pievēršot boḷševiku režīma izpētei no sistēmas viedokḷa un nesniedzot tam nepārprotamu vērtējumu. Iepriekš minētais nosaka raksta mērķi - atbildēt uz jautājumu, vai l̦eninisms ir jauna 
zinātne, kura izveidojusies marksisma radošas attīstības rezultātā, vai zinātnes viltojums?

Komunisma popularitāti K. Marksa dz̄̄ves laikā var izskaidrot ar to, ka šī ideoloǵija atbilst izsenajiem cilvēku sapņiem par gaišāku nākotni, kurā tiktu izskausta netaisnība, nabadzība, nebūtu karu un vardarbības. K. Marksa komunisma uzcelšanas koncepcija ir utopija, bet reizē arī lioti vilinoša nākotnes vīzija. Nav brīnums, ka tā pievilka ļoti daudzus cilvēkus dažādās pasaules valstīs. Viṇu vidū bija arī V. Ļeņins, kurš iesāka savu politisko karjeru kā Krievijas Sociāldemokrātiskās strādnieku partijas (KSDSP) biedrs. 1903. gadā KSDSP kongresā viņš no sākotnējā mazākuma izveidoja vairākumu, ko nodēvēja par lielinieku jeb boḷ̌seviku (revolucionāro sociāldemokrātu) bloku.

\section{Marksisma radoš $\bar{a}$ attīstība}

Boḷševiki bija sociālistiskās revolūcijas piekritēji. Taču pat viṇu vidū valdīja pārliecība, ka saskaņā ar K. Marksa mācību sociālistiskā revolūcija Krievijā var notikt tikai pēc proletariāta uzvaras attīstītajās Rietumu valstīs. V. Luenins savos rakstos un runās nekad nekritizēja K. Marksa un F. Engelsa komunistiskās sabiedrības attīstības teoriju. Viņš pretendēja uz galvenā, īstenā marksista pozīciju un savos darbos centās pierādīt, ka vina galvenie oponenti neizprot K. Marksu. Lūk, esot radušies jauni apstākḷi, kas prasa radoši attīstīt $\mathrm{K}$. Marksa mācību, piemērojot to Krievijas īpašajiem apstākḷiem. Maskējoties ar radošu marksisma attīstību, V. L,enins veica dažas principiālas izmaiņas marksisma teorijā par sociālistisko revolūciju. Savā rakstā Par Eiropas Savienoto valstu lozungu viņš apgalvoja, ka "ir iespējama sociālisma uzvara sākumā nedaudzās vai pat vienā, atsevišķi ņemtā kapitālistiskā valstī”'. Ar šo valsti bija domāta Krievija. Saskan̄ā ar marksisma teoriju nacionālā norobežotība un pretrunas starp pasaules tautām arvien vairāk izzūd jau līdz ar kapitālisma attīstību, un proletariāta kundzība paātrina to izzušanu. K. Markss un F. Engelss rakstīja: "Apvienota, vismaz civilizēto zemju,

1 Lenin 1915, 1. rīcība ir viens no proletariāta atbrīvošanās pirmajiem nosacījumiem."2

V. Ļeņina mēgeinājumi sniegt zinātnisku pamatojumu savai jaunradei ir visai pretrunīgi un virspusēji. Savā grāmatā Imperiālisms $k \bar{a}$ kapitālisma augstākā stadija viņš rakstīja: "Monopoli, oligarhija, tieksme pēc kundzības, nevis pēc brīvības, kā arī nelielas bagātāko un varenāko nāciju grupas īstenotā arvien lielāka skaita mazo un vājo nāciju ekspluatācija - tas viss radīja raksturīgās, atškikirīgās imperiālisma pazīmes, kādēl tas raksturojams kā parazìtiskais vai pūstošais kapitālisms."’3 Taču ši paša sacerējuma turpinājumā ir atzịts: "Būtu kḷūdaini domāt, ka ši pūšanas tendence izslēdz ātru kapitālisma augsmi. Kapitālisms kopumā attīstās neizmērojami straujāk nekā iepriekš, tikai šĩ attīstība kḷusst ne tikai kopumā nevienmērīgāka, bet nevienmērība izpaužas arī pašu stiprāko kapitāla valstu trūdēšanā (Anglija)." Iznāk, ka trūdošais kapitālisms var paātrināti attīstīties, un vēl kā! V. L,eņins konstatēja, ka "kapitālisms kḷuva par imperiālistisko kapitālismu tikai noteiktā, ḷoti augstā savas attīstības pakāpē .. kad .. parādījās pārejas laikmeta pazīmes no kapitālisma uz daudz augstāku sabiedriski ekonomisko iekārtu"5. Diemžēl viņš neapgrūtināja sevi ar šo pazīmju aprakstu attiecībā uz Krieviju. Saskaņā ar pirmsrevolūcijas Krievijas statistikas datiem ražošanas spēku un ražošanas attiecību attīstības ziņā Krievija tālu atpalika no ASV un Rietumeiropas valstīm. Krievijā kapitālisms atradās attīstības sākuma stadijā. Kāpēc vienā, turklāt neattīstītā valstī pēkšņi ir tik krasi izmainījušās sabiedrības attīstības likumsakarības, ka iespējama pāreja uzreiz no feodālisma uz augsti attīstīto komunistisko sabiedrību? Ar kādiem fantastiskiem līdzekḷiem V. L̦eṇins cerēja veikt šādu grandiozu uzdevumu? Bez nepieciešamās materiālās un tehnoloǵiskās bāzes, bez proletariāta šķiras un partijas?

V. L,enina Kopoto rakstu 26. sējuma priekšvārdā šì viņa tēze ir iztēlota kā geniāls atklājums un jauna sociālistiskās revolūcijas teorija. Tikai ši jaunā teorija ir krasā pretrunā

\footnotetext{
2 Marx, Engels 2017, 479.

3 Lenin 1917, 422.

4 Turpat, 422-423.

5 Turpat, 385.
} 
ar marksistisko sociālistiskās revolūcijas teoriju, pēc kuras revolūcija pirmām kārtām ir nepieciešama cilvēku apziņā. Komunistisko sabiedrību veido cilvēki, kuru galvenais dzīves saturs ir garīgās vērtības.

Saskaņā ar marksisma principiem pāreja uz komunismu prasa adekvātu visu savstarpēji saistìto ražošanas attiecību un ražošanas spēku elementu attīstības līmeni. Kapitālisma attīstības sākuma stadijā buržuāzija ir uzskatāma kā "revolucionāra šḳira, kā lielindustrijas nesēja .. Buržuāzija atrodas nemitīgā cīṇā: sākumā pret aristokrātiju, vēlāk pret to buržuāzijas daḷu, kuras intereses nonāk pretrunā ar industrijas attīstību .. Tādā pašā mērā, kādā attīstās buržuāzija, tas ir, kapitālisms, attīstās proletariāts, - mūsdienu strādnieku šķira".

Proletariāta vairākums veidojas sabiedrības vēsturiskās attīstības procesā: "Līdz ar rūpniecības attīstību proletariāts rekrutēsies no visām iedzīvotāju šķirām .. Vidējās kārtas zemākie slāṇi - sīkrūpnieki, sīktirgotāji un rantjē, amatnieki un zemnieki - visas šìs šķiras noslīd proletariāta rindās."”

Abu autoru redzējumā proletariāta diktatūra tādējādi veidojas kā vēsturiski pirmā vairākuma diktatūra: "Proletāriskā kustība ir milzīgā vairākuma patstāvīga kustība milzīgā vairākuma interesēs." ${ }^{8}$ Krievijā pagājušā gadsimta sākumā proletariāts vēl bija niecīgā mazākumā. Lauku iedzīvotāju īpatsvars veidoja $82,3 \%{ }^{9}$. Rūpniecības attīstībai Krievijā trūka kapitāla, inženieru un kvalificētu strādnieku, kuru sagatavošanu ievērojami apgrūtināja iedzīvotāju zemais izglītības līmenis. Tikai 13,3\% no Krievijas impērijas iedz̄ivotājiem, kuri vecāki par 50 gadiem, prata lasìt un rakstīt, savukārt lasītpratēju īpatsvars vecuma kategorijā no 9 līdz 49 gadiem bija 26,6\% ${ }^{10}$. Pirmsrevolūcijas Krievijā proletariāts bija niecīgā mazākumā. Iedzīvotāju vairākumam bija visai aptuvens priekšstats par komunismu, un daudzi no viņiem neatbalstīja V. L,eņina sociālistiskās revolūcijas programmu.

\footnotetext{
${ }^{6}$ Marx, Engels 1848, 11.

7 Marx, Engels 2017, 472.

8 Turpat, 473.

9 Prokopovič 1952, 55.

10 Turpat, 111.
}

Viña uzskati par proletariāta diktatūras dibināšanas metodēm un līdzekḷiem ir krasā pretrunā ar marksisma principiem. Kā raksta K. Markss un F. Engelss, proletariāta diktatūras dibināšanas demokrātisko raksturu lielā mērā veicinās tas, ka "rūpniecības attīstība grūž arvien jaunus valdošās šķiras pārstāvjus proletariāta rindās .. Viṇu skaitā - dą̧a buržuāzisko ideologu, kuri ir pacēlušies līdz sabiedrības vēsturiskās attīstības teorētiskai izpratnei""l.

Pirmais radošais V. L̨eņina atklājums par sociālisma uzvaru vienā valstī radīja vairākas problēmas ar proletariāta diktatūru, demokrātiju un revolūcijas vadošo spēku. Kad proletariāts ir niecīgā mazākumā, kā tas bija pirmsrevolūcijas Krievijāa, tad proletariāta diktatūras dibināšana demokrātiskā ceḷā ir loti problemātiska. Krievijā proletariāts kā škira tik tikko sāka veidoties, un šādos apstākḷos proletariāta partija kā tautas masu vadošais spēks nevarēja tikt izveidota. V. L,eņins gan apgalvoja, ka šādu uzdevumu veikšot "jauna tipa partija".

Tādējādi viņš turpināja radošu marksisma attīstību, sniedzot atškirīgu proletariāta un demokrātijas interpretāciju. Runā Viskrievijas transporta strādnieku kongresā 1921. gada 27. martā, runājot par proletariāta diktatūru, viņš paskaidroja: "Šim terminam ir jēga tikai tad, kad škira zina, ka tā viena ņem savās rokās politisko varu, un neapmāna ne sevi, ne citus ar runām par visas tautas vēlēto un svētīto varu." $" 12$

Savu demokrātijas izpratni V. L,enins izklāstīja jau III Krievijas strādnieku, kareivju un zemnieku padomju kongresā, kas notika 1918. gada 25. janvārī: "Kamēr revolūcija neizgāja no buržuāzijas ietvariem, mēs prasījām demokrātiju, bet, tikko kā mēs ieraudzījām pirmās sociālisma pazīmes visā revolūcijas gaitā, mēs stingri un apṇēmīgi nostājāmies par proletariāta diktatūru." ${ }^{13}$ Oponentiem viņš, kā parasti, neatbild pēc būtības, nosaukdams tos par renegātiem, idiotiem, politiski neizglītotiem cilvēkiem. Pret saviem oponentiem V. L,eņins ir lıoti kategorisks, piem., brošūrā Padomju varas panākumi un grūtības: "Mēs,

\footnotetext{
11 Marx, Engels 2017, 472.

12 Lenin 1970a, 132.

13 Lenin 1974, 280.
} 
protams, neesam pret vardarbību, mēs smejamies .. un sakām, ka .. ir jābūt vai nu proletariāta diktatūrai, vai buržuāzijas diktatūrai. Kas runā citādi, ir vai nu idiots, vai politiski tik neizglītots, ka vinuu nevar laist ne tikai tribīnē, ir kauns pat pielaist tādu sapulcē."'14 Šāda proletariāta diktatūras un demokrātijas izpratne atklājas arī daudzos citos viņa sacerējumos.

V. L,enina atkläjumi neguva ne II Internacionāles vadītāju, ne arī kopumā sociālistu un pilsonisko demokrātu atbalstu. Grāmatas Imperiālisms kā kapitālisma augstākā stadija ievadā viņš rakstīja: "Sevišķa vērība šajā grāmatin̄ā veltīta kautskismam - tās starptautiskās idejiskās strāvas kritikai, kuru visās pasaules zemēs reprezentē redzamākie teorētiķi, II Internacionāles vadoṇi un ļoti daudz sociālistu, reformistu, pacifistu, buržuāzisku demokrātu, mācītāju." ${ }^{15}$ Būtībā viņam nācās atzīt, ka tikpat kā visi Eiropas un Amerikas sociālistisko partiju un arodbiedrību līderi ir negatīvi noskaņoti pret viņa jauno sociālistiskās revolūcijas teoriju. Savus oponentus V. L,enins apvainoja par piln̄igu atteikšanos no marksisma revolucionārajiem pamatiem. Vērtējot viṇa revolūcijas programmu, ir vietā atcerēties, ka, saskaņā ar K. Marksa un F. Engelsa vērtējumu, "pirmie proletāriešu atbrīvošanās mēǵinājumi cieta neveiksmi tieši tādēḷ, ka proletariāts vēl bija vāji attīstīts un .. revolucionārā literatūra, kura šo proletariāta kustību iedvesmoja, pēc sava satura bija reakcionāra"16.

Neraugoties uz daudzo oponentu kritiku, V. Ļeņins uzrakstīja Aprīḷa tēzes ${ }^{17}$, kurās izklāstīja boḷševiku programmu pirmsrevolūcijas periodam. Viņam oponēja ne tikai meņševiki jeb mazinieki un eseri (sociālisti revolucionāri), bet arī daži lielinieku jeb boḷševiku līderi. Septītajā KSDSP(b) (b - boḷševiku) konferencē Aprīḷa tēzes pieñēma ar nelielu balsu vairākumu, pateicoties neizglītotās provinces atbalstam.

\footnotetext{
14 Lenin 1969, 56.

15 Lenin 1917, 7.

16 Marx, Engels 2017, 490.

17 Lenin 1917a, 1.
}

\section{Totalitārais režīms zem komunisma maskas}

1917. gada Oktobra revolūcijā (jeb, kā to sākotnēji sauca arī paši boḷ̌šviki, - apvērsumā), gluži pretēji K. Marksa komunisma koncepcijai, Krievijā nodibināja niecīga mazākuma diktatūru pār milzīgu tautas vairākumu. Šo niecīgo mazākumu veidoja nevis proletariāts, bet jauna tipa partijas t. s. nomenklatūra jeb pašiecelta elite - politiskās varas aparāta darbinieki.

Kāda bija š̄i jaunā partija, pārliecinošu liecību sniedz tās izraisītais masu terors, kā arī sociālā un ekonomiskā politika. Nezaudējot ne mirkli, notika inteliǵences padzīšana no valsts, sarkanā terora izvēršana, komunistiskās revolūcijas idejas apdullināto cilvēku iesaistīšana režīma sargu pulkā, melīgas propagandas izvēršana. V. Ĺenins pats bija galvenais sarkanā terora iedvesmotājs. Par to liecina viņa raksti, runas, telegrammas. 1918. gada augustā viņš nosūtīja telegrammu uz N̦ižnijijnovgorodu un Penzu: “.. pakārt (noteikti pakārt, lai tauta redzētu) ne mazāk par simts kulaku, bagātnieku un asinssūcēju .. Izdarīt tā, lai pa simts verstīm tauta redzētu, drebētu, zinātu, kliegtu: žņaudz un nožņaugs asinssūcējus - kulakus"18 (kulaki - budži).

Boḷševiki likvidēja visas pārējās Krievijas politiskās partijas, to laikrakstus, iznīcināja grāmatas, mākslas darbus un to autorus. Boḷševiku nomenklatūras uzdevums bija iedvest padomju cilvēku apziņā izkroplotu pasaules ainu. Inteliǵgences jeb intelektuāḷu izdzī̌sanai ārpus Krievijas robežām veica unikālu policejisku operāciju, kura pazīstama kā filozofu kugíis $^{19}$. Inteliğences vajāšana turpinājās arī vēlākajos gados, tāpēc ka tā bija viens no galvenajiem boḷševiku varas apdraudējumiem. Boḷševiki nevarēja uzticēt buržuāziskajai inteliǵencei bērnu un pieaugušo analfabētu izglītošanu, tādēl ka būtībā viniiem bija vajadzīgi apmācīti vergi. Pazīstamais krievu rakstnieks Maksims Gorkijs, uzzinājis par daudzu zinātnieku ieslodzī̌anu cietumā, 1919. gada 15. septembrī uzrakstīja vadonim sašutuma pilnu vēstuli. Atbildē V. Ļeņins apalvoja, ka

18 Cit. pēc Bajmuhametov 2018.
19 Lenin $1975,265$. 
zinātnieku - kadetu (konstitucionālo demokrātu) atbalstītāju - apcietināšana novērsīšot iespējamos dumpjus un sazvērestības, kuru rezultātā varētu tikt nogalināti desmitiem tūkstošu strādnieku un zemnieku (!). ${ }^{20}$ Ar katru nākamo boḷševiku režīma soli viņu īstenie nodomi atklājās arvien skaidrāk. Jau no pirmajām varas dienām tika uzṇemts virziens uz valsts militarizāciju, maskējoties ar valsts elektrifikācijas plānu.

Runājot par proletariāta diktatūras jēgu, V. L̦eņins uzsvēra, ka tās mērķis ir uzcelt sociālismu, iznīcināt sabiedrības škelšanu škirās, likvidēt cilvēku ekspluatāciju ${ }^{21}$. Bet, tikko kā vara bija saņemta, viņš aizmirsa šo cēlo sociālistiskās revolūcijas mērķi. Boḷševiki izveidoja jaunu ekspluatatoru kastu, kurai politiskā vara kalpoja kā ekspluatācijas instruments un labklājības avots. Kastā ietilpa boḷševiku partijas un padomju varas aparāts un jaunā režīma bruņotie sargi - Viskrievijas Ārkārtējās komisijas (čekas) darbinieki. Viṇi saṇēma augstas kvalitātes importa un iekšzemes ražojuma pārtikas un rūpniecības preces, kā arī pakalpojumus par simboliskām cenām.

Nomenklatūras darbinieki dzīvoja savā atsevišḳā pasaulē. Ikdienas darba dzīve viņiem bija kā teātris, kurā nepārtraukti jāmelo par drīzo komunisma iestāšanos, par diktatora geniālo valsts vadību, partijas nemitīgo cīṇu par mieru, par pārejošām grūtībām komunisma celtniecībā.

1920. gada 22. aprīlī - vadoņa 50 gadu jubilejā - padomju avīzes bija pārpildītas ar slavas pilniem rakstiem par viņa dzīvi un revolucionāro darbību. Bet valstī valdīja haoss, ekonomika bija tuvu pilnīgam sabrukumam. Kad boḷševiku vara karājās mata galā, V. Ḷeņins bez svārstīšanās īstenoja daḷēju kapitālisma restaurāciju, ko viņš maskēja ar t. s. jauno ekonomisko politiku jeb nepu. Šāds lēmums vēlreiz apliecināja, ka kapitālisms Krievijā vēl ne tuvu nebija izsmēlis savu potenciālu.

Jauna tipa partija jau 1918. gadā proletariāta vārdā ieviesa neekvivalentu lauksaimniecības produktu piespiedu apmainu pret rūpniecības precēm, kas pavēra iespēju boḷševiku režīmam aplaupīt proletāriešiem

\footnotetext{
20 Lenin $1970,47-49$

${ }^{21}$ Lenin 1969, 385.
}

draudzīgo šķiru - zemniekus. Cariskajā Krievijā 1913. gadā, lai varētu nopirkt arklu, zemniekam vajadzēja pārdot 20 pudus graudu, bet 1923. gadā - 150. Tādā pašā līmenī bija cenu attiecības starp lauksaimniecības ražojumiem un plaša patēriņa precēm. Boḷševiku direktīvi uzstādīiās lauksaimniecības ražojumu cenas nevarēja kompensēt pat to pašizmaksu. ${ }^{22}$

Jaunās ekonomiskās politikas rezultātā lauksaimniecības attīstības tempi 1921.1928. gadā bija visaugstākie visā PSRS pastāvēšanas laikā, bet graudaugu ražošanas apjoms pieauga apmēram divas reizes. 1928. gadā pārtikas produktu patēriņš, rēḳinot uz vienu iedzīvotāju, Padomju Savienībā bija nedaudz augstāks salīdzinājumā ar pirmsrevolūcijas 1913. gadu. $^{23}$

Josifs Stalịns tālāk attīstīja V. Lenina izveidoto totalitārās varas sistēmu, visādi pastiprinot tās represīvo raksturu. Valsts militarizācijas forsēšanas un kolektivizācijas rezultātā tika nomērdēti badā miljoniem padomju cilvēku. 1931. un 1932. gadā graudaugu raža bija tikai nedaudz zemāka par vidējo ilggadējo. Kā rakstīja pat boḷševiku laikraksts Pravda, "bēda pienāca tāpēc, ka labību piespiedu kārtā izṇēma .. kā kolhozos, tā viensētās, lai izpildītu nereālos, patvalīigi, pretrunā ar piecgades plānu uzstādītos industriālās attīstības uzdevumus" ${ }^{24}$. Boḷševikiem bija vajadzīga valūta, lai palielinātu ražošanas iekārtu importu tanku un lielgabalu ražošanai. Tieši tādēḷ J. Stalıina valdība 1931. gadā, neraugoties uz augošo badu, palielināja graudaugu eksportu līdz 51,8 milj. centneru, salīdzinot ar 48,4 milj. centneru 1930. gadā. $^{25}$

Boḷševiku režīms uzturēja cilvēkos pārliecību, ka, pateicoties partijas un personiski J. Staļina gudrajai vadībai, padomju tauta gūst vienu grandiozu uzvaru pēc otras.

8. ārkārtas Vissavienības padomju kongress, kas notika 1936. gada 5. decembrī, pieņēma konstitūciju un deklarēja sociālisma uzcelšanu Padomju Savienībā. Taču tika noklusēts, ka padomju cilvēki bija sliktāk apgādāti ar pārtiku, apgèēbu un apaviem nekā

\footnotetext{
22 Nikonov 1995, 137.

23 Doklad 1955.

24 Il'jin 1988.

25 Turpat.
} 
pusfeodālajā cara Krievijā. Gaḷas patēriņš, rēḳinot uz vienu iedzīvotāju, Padomju Savienībā 1940. gadā bija 89\%, piena $92 \%$ un zivju $78 \%$ no 1913. gada līmeņa Krievijas impēri$\mathrm{jā}^{26}$. Vien̄̄gā ìsteni demokrātiskā konstitūcija pasaule pastāvēja tikai uz papīra un kalpoja propagandas interesēm.

Dažas nedēlas pēc konstitūcijas pieṇemšanas sākās drausmīgās 1937. gada masu represijas. J. Stalina attaisnojums ir fantastisks škiru cīṇas saasināšanās sakarā ar sociālisma celtniecības pabeigšanu! Kā var saasināties šķiru cīņa, kad nogalināto un emigrējošo tautas ienaidnieku skaits ir mērāms miljonos un vienlaikus gandrīz visa tauta sastāv no strādniekiem un darba zemniekiem? Bet ir pamats uzskatīt, ka sarkanā terora un apziņas manipulāciju ietekmētās padomju tautas vairākums ticēja, ka visapkārt joprojām ir ienaidnieki, spiegi, kaitnieki. Apmēram pusei no Vissavienības trieciennieku brigāžu kongresa dalībniekiem bija tikai pamatskolas izglîtība, bet piektā dạ̧a no viņiem nekad nebija mācījusies skolā. "Bet vini bija stipri ar citu: bezgalīgu un nelokāmu ticību ḷeņiniskajām Oktobra idejām, partijas lozungiem un apnēmību ar saviem darbiem paātrināt vēstures attīstību." ${ }^{27}$

Dzīvot pusbadā, pastāvīgās bailēs par savu dzīvību, toties ar laimes sajūtu, ka pirmoreiz pasaules vēsturē ir dota iespēja dzīvot sociālistiskajā sabiedrībā! Stāvoklis cilvēktiesību jomā bija katastrofāls. Jāatzīst, ka boḷševiku sociālisms ne par matu nepietuvināja K. Marksa iecerēto brīvo cilvēku apvienību.

Padomju cilvēku apzin̄ā pakāpeniski tika iedvesta izkroplota pasaules aina, kurai bija maz līdzības ar dzīves īstenību. Grūti atrast kaut cik nozīmīgu parādību vai notikumu boḷševiku režīma laikā, kurš būtu tīrs no meliem. V. L,eninins, jāatzīst, ǵeniāli falsificēja K. Marksa un F. Engelsa komunistiskās sabiedrības uzcelšanas koncepciju. Vilinošās komunisma utopijas aizsegā viņam izdevās izveidot totalitāru cilvēku paverdzināšanas sistēmu, iedvest cilvēku apzin̄ā pārliecību, ka gaišās nākotnes vārdā ir nepieciešama masveida cilvēku iznīcināšana. Vadonis pievērsa lielu vērību psiholoǵiskai ienaidnieku tēlu konstruēšanai,

\footnotetext{
26 Doklad 1955.

27 Il'jin 1988a.
}

naida iedvešanai pret buržuāziju, kulakiem, garīdzniekiem, amerikāṇu, angḷu, franču imperiālistiem...

Pārbūves sākumā kompartijas rupors laikraksts Pravda publicēja rakstu sēriju ar nosaukumu Véstures lappuses. Pat šie ideologi bija spiesti atzīt, ka "likumu pārkāpumi, represijas un patvaļa pārvērta administratīvo komandu ekonomiku par administratīvo karātavu ekonomiku"28.

Izsmeḷošu toreiz jaunās varas raksturojumu sniedzis izcilais krievu operdziedātājs Fjodors Šal̨apins: "Brīvība pārvērtās par tirāniju, brālība par pilsoṇu karu .. Celtniecība pārvērtās par totālu postu, un mīlestība uz cilvēces nākotni izvērtās par naidu un laikabiedru ciešanām., ${ }^{29}$

Ĺeninisma ideoloǵijai un agresīvajai propagandai bija nozīmīga loma 20. gadsimta globālo katastrofu norisēs, ieskaitot Otro pasaules karu un viltus sociālisma nometnes izveidošanu ar vairākām Eiropas, Āzijas un Dienvidamerikas valstīm. Totalitārisma idejas zem komunisma maskas vēl joprojām gūst ne tikai Ķīnas un dažu trešās pasaules valstu (Venecuēla, Zimbabve), bet arī atsevišku Eiropas un Amerikas kreiso partiju, politiku un zinātnieku atbalstu. Tā ir starptautiska mēroga problēma, kas pelna ievērību kā īpaša pētījuma priekšmets.

Boḷševiku režīma pētnieki nereti, atzīstot tā rīcības pilnīgu neatbilstību marksisma principiem, visai atzinīgi vērtē PSRS sasniegumus sociālisma celtniecībă $\bar{a}^{30}$.

Boḷševiku režīma idealizētāju vidū nevar neatzīmēt ASV vēsturnieku Stīvenu Koenu (Stephen Cohen). Savos sacerējumos S. Koens cenšas pierādīt, ka V. Lenina viltus komunisma idejas bija iespējams īstenot bez boḷševiku sarkanā terora ${ }^{31}$ un pastāvēja alternatīva Stą̧ina režīmam Nikolaja Buharina personā. N. Buharins bija mērenāks boḷšseviks, salīdzinot ar J. Staḷinu, taču arī viņš rakstīja, ka "proletāriskie spaidi visās to formās, sākot ar nošaušanu un beidzot ar darba klausību, veido komunistiskā cilvēka formēšanas metodes,

\footnotetext{
28 Il'jin 1988a.

9 Šaljapin 1989, 241.

30 Sal. Daniels 2001, 436.

31 Cohen 1985.
} 
izmantojot kapitālistiskā laikmeta cilvēku materiālu"32. Dīvaini, ka S. Koens, rakstot grāmatu par N. Buharina dzìvi, nav to pamanījis.

V. L Lenina veiktais marksisma viltojums ar pretenziju uz jaunu zinātni vēl līdz šim nav visā pilnībā atmaskots. Vēl pēc simts gadiem viņa izveidotā cilvēku paverdzināšanas sistēma atražo sevi desmitiem miljonu cilvēku apzin̄ā visās bijušajās Padomju Savienības savienotajās republikās. Ilgstoša totalitārā režīma pastāvēšana acīmredzot noved pie grūti pārvaramām negatīvām izmaiṇām cilvēku sabiedrībā.

Pirmām kārtām tika iznīcināti patstāvīgi domājoši cilvēki, kas apveltīti ar līdera dotībām. Arī manās pārrunās un diskusijās ar simtiem padomju cilvēku izrādās, ka vairākumam no viņiem totalitārā režīma apziņas manipulācijas ir atstājušas lielāku vai mazāku ietekmi uz domāšanas veidu, uzticību oficiālajiem un neuzticību ārzemju informācijas avotiem. Ļoti daudzi vēl joprojām tic (citādi to nevar nosaukt), ka ASV grib uzbrukt Krievijai, savukārt citi baidās domāt, kad ir runa par strīdīgiem politiskiem notikumiem. Informācija no ārzemēm vinuus tikpat kā nesasniedz. Šādos apstākḷıs ir nepieciešams pārskatīt informatīvo pasākumu izstrādes koncepciju un to īstenošanas tehnoloǵijas. Ir vajadzīgs pētījums par apziņas manipulāciju daudzpusīgo ilgtermiņa

32 Buharin 1920, 146. ietekmi uz smadzeņu darbību un cilvēku psihisko veselíbu totalitāro režīmu apstākḷos.

\section{Secinājumi}

Marksisms un l̦eninisms ir divas nesavienojamas pasaules sabiedrības attīstības koncepcijas, savukārt marksisms-ḷeņinisms ir V. Luenina izdomājums, kura mērḳis ir ar komunisma ideāliem maskēt totalitārisma ideoloǵiju un totalitāras valsts iekārtas praksi. Viṇš izstrādāja projektu totalitārās varas režīmam. Maskējoties ar jaunām kapitālisma attīstības likumsakarībām un Krievijas īpašajiem apstākḷiem, viṇš kardināli izmain̄ija K. Marksa un F. Engelsa sociālistiskās revolūcijas teoriju. Rakstot par Krievijas apstākḷiem, kuri prasot nekavējoties revolucionārā ceḷā pāriet uz komunistisko sabiedrību, V. Lenins ignorēja principiāli svarīgākās marksisma tēzes. Īsten̄̄bā šie apstākḷi - feodālisma paliekas, zemais iedzīvotāju izglītības līmenis un tehnologiskā atpalicība - pat teorētiski izslēdza komunistiskās sabiedrības veidošanu.

Ḷeṇinisms ir varmācīga cilvēku apziņas pārveidošana, savienojot represīvas metodes ar ideoloǵiskajām - propagandu, izglīīîbu, ideologísku cilvēku apstrādi darbavietās -, tādējādi iznīcinot komunisma ideālus un nespējot radīt to īstenošanai nepieciešamo materiāltehnisko bāzi. Vēl vairāk, boḷševiku partijas nomenklatūra nebija ieinteresēta komunisma veidošanā - tā būtu viņu nāve, gals viņu varai, privileg̣êtajam statusam un vinu labklājībai.

\section{VĒRES}

Bajmuhametov, S. (2018) Smejsja, palač! Novaja gazeta (04.03.2018.), 23, 20.

Buharin, N. (1920) Ekonomika perehodnogo perioda. Moskva : Gosudarstvennoe izdatel'stvo.

Cohen, S. (1985) Rethinking the Soviet Experience: Politics and History since 1917. London : Oxford University Press.

Daniels, R. V. (2001) A Documentary History of Communism in Russia. Rev. ed. Burlington : University of Vermont Press.

Doklad CSU i Instituta ekonomiki Akademii nauk SSSR (1955).

Il'jin, A. (1988) Kollektivizacija: kak eto bylo. Pravda, 260, 3.

Il'jin, A. (1988a) Industrializacija v SSSR: pervye pjatiletki. Pravda, 302, 6.

Lenin, V. I. (1909) Materializm i empirokriticizm. Moskva : Zveno.

Lenin, V. I. (1915) O lozunge soedinennih štatov Evropy. Socialdemokrat, 44, 1.

Lenin, V. I. (1917) Imperializm kak vysšaja stadija kapitalizma. Petrograd : Žizn' i znanie. 
Lenin, V. I. (1917a) Zadači proletariata v dannoj revolucii: Aprel'skie tezisy. Pravda, 26, 1.

Lenin, V. I. (1969) Uspehi i trudnosti Sovetskoj vlasti. Polnoe sobranie sočinenij, 38. Moskva : Izdadel'stvo političeskoj literatury.

Lenin, V. I. (1970) Pis'mo Gor'komu. Polnoe sobranie sočinenij, 51. Moskva : Izdadel'stvo političeskoj literatury.

Lenin, V. I. (1970a) Reč' na Vserossijskom s'ezde transportnyh rabočih 27 marta 1921 goda. Polnoe sobranie sočinenij, 43. Moskva : Izdadel'stvo političeskoj literatury.

Lenin, V. I. (1974) Reč' na Tret'em s'ezde sovetov rabočih, soldat i krest'jan 12 (25) janvarja 1918 goda. Polnoe sobranie sočinenij, 35. Moskva : Izdadel'stvo političeskoj literatury.

Lenin, V. I. (1975) Zasedanie Politbjuro i Orgbjuro CK 19. maja 1922. Polnoe sobranie sočinenij, 51. Moskva : Izdadel'stvo političeskoj literatury.

Marx, K.; Engels, F. (1848) Manifest der kommunistischen Partei. London : Die Office der Bildungsgessellshaft für Arbeiter.

Marx, K.; Engels, F. (2017) Deutsche Ideologie. Berlin : De Gruyter Akademie Forschung, 715.

Nikonov, A. A. (1995) Spiral' mnogovekovoj dramy: agrarnaja nauka i politika Rossii (XVIII-XX stol.). Moskva : Enciklopedija rossijskih dereven', 574.

Prokopovič, S. N. (1952) Narodnoe hozjajstvo SSSR, 1. New-York : Izdatel'stvo im. Čehova.

Šaljapin, F. I. (1989) Maska i duša. Moskva : Moskovskij rabočij. 